\title{
Pelatihan Keterampilan Menulis dalam Korespondensi Berbahasa Inggris, Menerjemahkan serta Keterampilan Menggunakan Grammarly, Google Translate, dan Google Drive di Sekolah Menengah Kejuruan KSATRYA, Rawasari, Jakarta Pusat
}

\author{
Elfa Setiawan ${ }^{1}$, Dinda A Rahman ${ }^{2}$, Rudi Kristanto ${ }^{3}$ \\ Program Studi Ilmu Administrasi Publik, Fakultas Ilmu Administrasi, Institut STIAMI, Jakarta, Indonesia \\ elfa.setiawan@gmail.com,dinda.auliarahman@gmail.com; zonapurple@yahoo.co.id
}

\section{ARTICLE INFO}

Keywords:

Business Correspondence

Google Drive

Google Translate

Grammarly

Translation Skills

Training

Writing skills

\section{ABSTRACT}

The development of the world of education in the 21st century is now entering an era marked by the onslaught of the information technology revolution and the formation of the economic order and global relations, thus demanding an output of educational outcomes and outcomes that are in line with the demands of the world of work. The ability to communicate both in Speaking and writing is one of the abilities that must be mastered by everyone.

The purpose of this Community Service Activities is to provide understanding and skills to vocational students in improving English language skills, particularly written communication skills in the business world as well as practical skills in translating documents documents or articles in English. The achievements of this service are increasing knowledge, insight, and English correspondence skills among vocational high school students, optimizing the use of online-based English Learning Tools such as Google Translate, Grammarly and Google Drive. The training activity was held for 4 hours on October 30, 2019, in the form of lectures, question-answers, and hands-on practice using Translation Tools. There were 22 trainees, class XII students of SMK Ksatrya, Cempaka Putih Barat, Central Jakarta. Based on the feedback from the participants, the training activities are very good and beneficial for them.

This activity is not only limited to the training but is expected to be the beginning of the collaboration between the STIAMI Institute and the Ksatrya Vocational School in the future, to conduct other English language training with different topics or themes.

\section{A. PENDAHULUAN}

Pada era tatanan masyarakat global sekarang ini, kemampuan berkomunikasi dengan menggunakan bahasa internasional terutama bahasa Inggris merupakan kecakapan hidup yang sangat penting dalam pergaulan. Seringkali kita dengar, aspek kelemahan yang paling menonjol dari para tenaga kerja Indonesia adalah lemahnya kemampuan berbahasa Inggris. Banyak orang Indonesia yang cerdas dan bertalenta unggul tapi tidak mampu berdialog dengan lugas, tidak mampu berbagi ide, gagasan, serta pemikiran-pemikiran maju karena terkendala bahasa.

Untuk itu, kondisi di atas seharusnya menjadi perhatian kita bersama dalam rangka peningkatan kemampuan berbahasa Inggris. Termasuk bagi para lulusan SMK, dimana mereka akan bersaing dengan sesama lulusan SMK dan lulusan dengan pendidikan yang lebih tinggi baik dari dalam maupun luar negeri. Apalagi bila melihat kenyataan yang sudah sangat mendesak bahwa era Masyarakat Ekonomi ASEAN (MEA) sudah mulai berjalan menginjak empat tahun sejak tahun 2015. Terbentuknya kawasan MEA selain memberikan peluang bagi kemajuan ekonomi dan bisnis yang sangat besar, dibalik itu juga dapat menjadi ancaman serius bagi SDM Indonesia. Kawasan pasar bebas seperti MEA mengandung makna terbukanya pertukaran barang dan jasa secara bebas di kawasan ASEAN, termasuk tenaga kerja. Oleh karenanya, lulusan SMK harus memiliki kualitas yang unggul di bidang vokasi dan bidang penunjang lainnya yang bersifat universal yaitu kemampuan 
berkomunikasi secara internasional serta kemampuan digital. Hal ini dikarenakan kemampuan berbahasa Inggris dan komputer adalah persyaratan yang secara frekuensi lebih banyak muncul di setiap lowongan pekerjaan dengan yang ada. Bidang keahlian apa pun, jika ditunjang dengan kemampuan bahasa Inggris dan komputer akan menjadi daya saing yang signifikan di pasar kerja.

Kondisi siswa SMK Ksatrya yang menjadi objek dalam kegiatan Pengadian Kepada Masyarakat ini secara umum belum memiliki kemampuan berbahasa Inggris yang baik, dalam berbicara maupun dalam tulisan. Kemampuan memahami bahasa Inggris siswa masih berada pada level pre-intermediate (menuju level menengah), dimana seharusnya kemampuan berbahasa Inggris kelas XII berada pada level pre-advanced. Fenomena yang ada dan terjadi pada siswa-siswa sekolah menengah atas atau kejuruan sekarang ini penggunaan bahasa Inggris dalam aktivitas sehari-hari baik di lingkungan sekolah atau di luar lingkungan sekolah sangat penting dan paling sering digunakan. Para siswa SMK Ksatrya khususnya cenderung sering menggunakan bahasa Inggris untuk menulis pesan singkat, menulis puisi, membuat laporan, dan lain sebagainya. Seluruh siswa SMK Ksatrya khususnya kelas XII memiliki gadget berupa telepon genggam yang selalu mereka bawa setiap hari ke sekolah. Walaupun penggunaan telepon genggam di dalam kelas diatur ketat oleh pihak sekolah, namun ada kegiatan pelajaran dimana siswa diperbolehkan untuk menggunakannya. Misalnya untuk mencari sumber-sumber atau referensi, untuk menerjemahkan wacana bahasa Inggris ke bahasa Indonesia atau sebaliknya, dan sebagainya. Kemajuan teknologi di bidang IT tidak maksimal digunakan oleh para siswa, Banyak siswa SMK Ksatrya yang belum mengetahui ada aplikasi online grammarly, google translate dan google drive dari browser terkenal Google.com yang jika dimaksimalkan akan sangat membantu siswa dalam berkomunikasi secara lisan maupun tulisan dalam bahasa Inggris.

Masalah esensi yang akan diangkat dalam kegiatan pengabdian Masyarakat ini erat hubungannya dengan salah satu kompetensi berbahasa, yaitu menulis (writing). Menulis merupakan salah satu keterampilan berbahasa yang memegang peranan penting, karena dengan menulis seseorang dapat berkomunikasi secara tidak langsung dengan orang lain, baik secara formal maupun informal. Di samping itu, menulis juga merupakan cara untuk mengekspresikan ide, pendapat, atau pengalaman untuk orang lain maupun diri sendiri.

Dalam Kurikulum KTSP saja pelajaran Bahasa Inggris standar kompetensi menulis menekankan pada kemampuan mengungkapkan berbagai makna interpersonal, ideasional, dan tekstual dalam berbagai teks tulis yang memiliki tujuan komunikatif, struktur teks dan ciri kebahasaan tertentu. Dalam kemampuan menulis yang harus dikuasai siswa, yakni kemampuan mengungkapkan berbagai makna dengan langkah-langkah pengembangan retorika yang benar di dalam teks tertulis fungsional pendek berbentuk narrative, recount, dan procedure dalam konteks sehari-hari. Ada beberapa indikator yang dapat dicapai oleh siswa dalam keterampilan menulis. Dalam penelitian yang akan dilaksanakan, peneliti berharap siswa mampu menghasilkan teks berbentuk naratif sederhana, yang merupakan salah satu indikator keberhasilan pembelajaran menulis. Namun untuk mencapai indikator tersebut, diperlukan usaha yang maksimal untuk membimbing siswa melalui tahapan-tahapan yang sederhana dan mudah dimengerti oleh siswa.

Pembelajaran yang dilakukan oleh guru bersifat monoton, yaitu siswa mendengarkan, duduk diam. Suasana kelas yang hening sehingga siswa pasif dan tidak dilatih untuk kreatif berpikir. Salah satunya adalah kreativitas guru dalam memilih, mendesain, melaksanakan, dan mengevaluasi pembelajaran, ternyata masih rendah, sehingga materi yang diajarkan kepada siswa tidak sesuai kebutuhan, ketertarikan minat, dan tingkatan siswa. Guru cenderung dengan cara konvensional, artinya bahwa guru meminta siswa menulis dan membantu mereka dengan pertanyaan lacakan (leading question) tetapi tanpa membimbing, memberi arahan kepada siswa cara atau proses menulis mulai dari outline atau kerangka hingga draf teksnya. Guru lebih menuntut siswa untuk menghasilkan sebuah tulisan atau teks tanpa adanya bimbingan yang sistematis, dan penekanan penilaian hasil tulisan siswa.

Kenyataan di lapangan, berdasarkan pengalaman dalam melaksanakan pembelajaran menulis di kelas menunjukkan bahwa keterampilan menulis sering ditakuti bahkan dihindari oleh siswa., hal ini disebabkan oleh terbatasnya kosakata (vocabulary) yang dimilikinya. Siswa mengalami kesulitan dalam mengungkapkan hal yang sederhana sekalipun dalam bentuk tulis, dan siswa kurang aktif 
dalam pembelajaran menulis, karena merasa jenuh dan kurang termotivasi untuk aktif dan mengeksplor gagasannya. Waktu yang digunakan sebagian didominasi oleh guru untuk menjelaskan, sehingga siswa tidak terfasilitasi untuk mengungkapkan gagasannya, baik dengan temannya maupun dengan gurunya. Pembelajaran menulis yang dilakukan kurang bervariasi dan kurang mengakomodir aspirasi siswa, dalam hal ini guru menceritakan secara lisan atau membaca teks, lalu melakukan tanya jawab tentang teks, kemudian siswa secara acak menyampaikan satu kalimat lisan apa yang diketahui berdasarkan teks lisan tersebut, kemudian dirangkai menjadi satu rangkaian cerita. Pada tahap berikutnya siswa menulis kembali cerita tersebut secara lengkap dengan menggunakan bahasa mereka sendiri, akan tetapi hasil tulisan yang dihasilkan oleh siswa belum muncul secara maksimal.

Berdasarkan observasi di dalam kelas dengan siswa yang dilakukan sebelum, selama dan setelah kegiatan pelatihan berlangsung, didapati bahwa mayoritas siswa mengalami kesulitan dalam semua aspek. Aspek kemampuan berbahasa Inggris meliputi receptive skills, meliputi listening dan reading, serta productive skills meliputi writing dan speaking.

Tujuan pelaksanaan kegiatan Pengabdian Kepada Masyarakat yang berbentuk pelatihan ini adalah 1) meningkatkan pemahaman dan keterampilan dasar tentang prinsip-prinsip penulisan business correspondence, tata bahasa dan struktur isi, model/layout, serta etika korespondensi khususnya dalam business correspondence, 2) meningkatkan pemahaman tentang prinsip-prinsip dasar dan kaidah menerjemahkan naskah/dokumen Inggris ke Indonesia, 3) memiliki keterampilan dasar dalam melakukan penerjemahan naskah/ dokumen Inggris ke Indonesia, 4) mengenal dan mampu menggunakan English learning tools, seperti grammarly, google translate, google drive, dan sebagainya.

\section{a. Identifikasi Masalah}

Berdasarkan latar belakang yang telah diuraikan pada paragraf sebelumnya, maka masalah yang teridentifikasi adalah :

1. Para siswa SMK Ksatrya secara umum belum mengetahui dan mengerti penggunaan $I T$ secara luas untuk membantu aktivitas belajar mereka.

2. Para siswa SMK Ksatrya secara umum belum mengetahui adanya aplikasi Grammarly, Google Translate, dan Google Drive dengan pengunaan secara luas.

3. Guru SMK Ksatrya menerapkan proses pembelajaran yang masih monoton sehingga siswa SMK Ksatrya hanya duduk diam, mendengarkan dan mencatat saja.

4. Sebagian besar siswa hanya memanfaatkan gadget berupa telepon genggam hanya untuk melakukan komunikasi sederhana, mendengarkan musik, bermain game online, atau sekedar bermain sosial media saja.

5. Pelajaran keterampilan menulis terutama dalam bahasa Inggris sering menjadi momok menakutkan bagi para siswa sehingga mereka cenderung menghindari, acuh bahkan tidak mau mempelajarinya.

\section{b. Pembatasan Masalah}

Berdasarkan Identifikasi Masalah di atas, penulis membatasi permasalahan pada:

1. Para siswa SMK Ksatrya tidak termotivasi untuk mengetahui lebih luas tentang korespondensi bisnis dalam bahasa Inggris.

2. Para siswa SMK Ksatrya belum mengetahui penggunaan aplikasi online dari Google, yaitu Grammarly, Google Translate dan Google Drive secara luas.

3. Penerapan proses pembelajaran di kelas masih sering menggunakan metode yang monoton, Teacher-Oriented dimana siswa menjadi tidak aktif dan tidak kreatif untuk menggali potensi diri mereka.

\section{c. Rumusan Masalah}

Masalah-masalah yang menjadi fokus pembahasan adalah sebagai berikut:

1. Bagaimanakah metode yang tepat agar para siswa menjadi tertarik dan senang untuk belajar lebih komprehensif lagi tentang korespondensi bisnis dalam bahasa Inggris? 
2. Bagaimanakah mengasah kemampuan dan keterampilan para siswa SMK Ksatrya dalam menerjemahkan kata, kalimat, paragrap bahkan teks dalam bahasa Inggris ke dalam bahasa Indonesia dan sebaliknya, menggunakan teknologi grammarly, google translate dan google drive?

Bagaimanakah menumbuhkan semangat para siswa untuk lebih kreatif dan aktif dalam memahami dan mengerjakan soal-soal dalam bahasa Inggris khususnya kemampuan dan keterampilan berkomukasi secara lisan maupun tulisan?

\section{d. Tujuan, Manfaat dan Kerangka Pemecahan Masalah}

Adapun tujuan dari kegiatan Pengabdian Kepada Masyarakat (PKM) dengan pendekatan model pelatihan ini sebagai berikut :

1) Meningkatkan pemahaman dan keterampilan dasar tentang prinsip-prinsip penulisan business

2) correspondence, tatabahasa dan struktur isi, model/layout, serta etika korespondensi khususnya dalam business correspondence.

3) Meningkatkan pemahaman tentang prinsip-prinsip dasar dan kaidah menterjemahkan naskah atau

4) dokumen Inggris ke Indonesia.

5) Memiliki keterampilan dasar dalam melakukan terjemahan naskah/ dokumen Inggris ke Indonesia.

6) Mengenal dan mampu menggunakan English learning tools, seperti grammarly, google translate, google drive, dan sebagainya.

\section{e. Manfaat kegiatan}

Kegiatan pelatihan ini diharapkan dapat memberikan manfaat bagi para siswa SMK, guru-guru SMK dan institusi sekolah sebagai berikut :

1. Manfaat Bagi Siswa

Adanya peningkatan wawasan, kemampuan dasar dan motivasi belajar di kalangan para siswa SMK dalam pembelajaran bahasa Inggris khususnya untuk keterampilan business writing skills for business correspondence dan translation skills baik manual maupun menggunakan mesin/program/aplikasi elektronik.

2. Manfaat Bagi Guru

Memberikan umpan balik untuk pengayaan materi business correspondence serta inovasi media bahan ajar berbasis elektronik di era digital dan industri 4.0.

3. Manfaat Bagi Institusi Sekolah

Memberikan bahan masukan Sekolah Menengah Kejuruan untuk pengembangan inovasi pembelajaran bahasa Inggris yang relevan dan dibutuhkan di era digital dan industri 4.0

\section{f. Kerangka Pemecahan masalah}

Alternatif pemecahan masalah dilakukan dengan mengadakan Pelatihan Keterampilan Menulis Dalam Korespondensi Berbahasa Inggris, Menerjemahkan Serta Keterampilan Menggunakan Grammarly, Google Translate, dan Google Drive, khususnya untuk menghadapi Siswa / peserta didik di SMK Ksatrya, Rawasari, Jakarta Pusat dimana diharapkan juga guruguru Bahasa Inggris khususnya dan guru-guru bidang studi lainnya memilki pengetahuan dan keterampilan dalam berkomunikasi secara efektif dengan siswa.

\section{B. TINJAUAN PUSTAKA}

\section{a. Pengertian Writing Skills}

Menulis atau writing adalah satu dari beberapa kemampuan terpadu dalam kemampuan untuk berkomunikasi. Dalam bahasa Inggris. Dalam kemampuan berbahasa Inggris, menulis 
selalu ada pada bagian akhir di samping kemampuan mendengar (listening), berbicara (speaking) dan membaca (Reading). Namun bukan berarti bahwa kemampuan menulis ini dianggap kurang penting. Menulis merupakan productive skill selain speaking karena bersifat menghasilkan kemampuan dalam diri penggunanya.

Bram (2012) menjelaskan pengertian menulis adalah "in principle, to write means to try to produce or reproduce written message", dengan arti menulis sebagai suatu usaha untuk membuat atau mereka ulang tulisan yang sudah ada.'.

Semi (2007:14) dalam bukunya menyatakan menulis adalah suatu proses kreatif memindahkan gagasan ke dalam lambang-lambang tulisan. Nurgiantoro (2009) menyatakan bahwa menulis adalah aktivitas produktif, yaitu aktifitas menghasilkan bahasa.

Menulis menurut Slamet (2008:72) merupakan kegiatan menggali pikiran dan perasaan mengenai suatu subjek, memilih hal-hal yang akan ditulis, menentukan cara menuliskannya sehingga pembaca dapat memahaminya dengan mudah dan jelas. Slamet sendiri mengungkapkan pendapatnya yaitu menulis sebagai kegiatan yang memerlukan kemampuan yang bersifat kompleks.

\section{b. Pengertian Business Correspondence}

Dalam kamus Webster (1993:131), dijelaskan definisi dari business correspondence adalah pertukaran informasi dalam format tertulis untuk proses kegiatan bisnis. Korespondensi bisnis dapat terjadi antara organisasi, dalam organisasi atau antara pelanggan dan organisasi. Korespondensi mengacu pada komunikasi tertulis antara orang-orang. Oleh karena itu komunikasi lisan atau komunikasi tatap muka bukanlah korespondensi bisnis.

Dalam Kamus Besar Bahasa Indonesia dinyatakan bahwa korespondensi hal tentang suratmenyurat. Korespondensi juga dapat diartikan dengan berkirim-kirim surat. Ini berarti bahwa korespondensi adalah kegiatan berkomunikasi menggunakan surat sebagai sarana. Seseorang yang berkomunikasi dengan menggunakan surat disebut koresponden. Berdasarkan penjelasan di atas dapat dikatakan bahwa korespondensi merupakansalah satu jenis komunikasi tertulis.

Korespondensi dapat terjadi antara seseorang dengan orang lain, antara seseorang dengan instansi atau sebaliknya, antara organisasi dengan organisasi, dan sebagainya.

\section{c. Pentingnya Business Correspondence}

Banyak eksekutif mengalami kesulitan melakukan korespondensi bisnis khususnya menulis Surat Bisnis. Keluhan ini sebenarnya tidak hanya dialami oleh pelaku bisnis Indonesia tetapi juga eksekutif negara maju di mana kebiasaan menulis sudah tertanam dengan baik sejak di sekolah.

Pakar Komunikasi Bisnis, Locker dan Kaczmareck (2015:54), mengatakan sekalipun top CEOs menekankan pentingnya komunikasi bisnis, realita menunjukkan 40 juta orang di Amerika Serikat mempunyai 'limited literacy skills', termasuk lulusan perguruan tinggi. Negara-negara Bagian mengeluarkan kurang lebih dari 220 juta dollar tiap tahun untuk program 'remedial writing' untuk pegawai, sementara dunia korporasi mengeluarkan US\$ 3,1 milyar untuk memperbaiki kemampuan menulis karyawan mereka. Teknik menulis Surat Bisnis berbeda dengan teknik membuat surat non-bisnis seperti surat pribadi atau ilmiah, terutama dalam hal strategi, nada dan gaya tulisan. Konsep lama yang lebih mementingkan kepentingan penulis atau pembuat surat tidak lagi dapat atau cocok dipakai dalam menulis Surat Bisnis dalam dunia komunikasi moderen.

Bisnis Koresponden bagi para siswa dan mahasiswa sangat penting dipelajari. Pengetahuan dan kemampuan lulusan-lulusan sekolah kejuruan dan juga lulusan universitas dituntut untuk mampu berkomunikasi secara efektif menggunakan bahasa Inggris baik dalam tulisan mapun lisan. Tidak dapat dipungkiri bahwa bidang ini kurang menarik dipelajari oleh para siswa kita karena di samping relatif sulit dan membosankan, Business Correspondence menggunakan bahasa Inggris sebagai bahasa pengantarnya. Di Indonesia, bahasa Inggris masih menjadi bahasa asing sehingga masih ada asumsi di masyarakat bahwa sesuatu yang bersifat asing akan dihindari 
untuk dipelajari. Jika dibandingkan dengan negara-negara lain di Asia, seperti Malaysia, Singapura, Pilipina dan lain-lain, dimana bahasa Inggris menjadi bahasa kedua mereka (second language). Bahkan bahasa Inggris menjadi bahasa yang mereka gunakan sehari-hari.

\section{d. Pengertian Translation}

Pengertian penerjemahan, ada pula yang menyebutnya dengan pengertian terjemahan, menurut Kamus Besar Bahasa Indonesia adalah menyalin atau memindahkan suatu bahasa ke bahasa lain.

Menurut Machali (2009:26), seorang ahli bahasa di The University of New South Wales (UNSW), penerjemahan adalah upaya "mengganti" teks bahasa sumber dengan teks yang sepadan dalam bahasa sasaran dan yang diterjemahkan adalah makna sebagaimana yang dimaksudkan pengarang.

Djuharie (2005:13) secara panjang lebar menjelaskan terjemahan lisan maupun tulisan memberi tekanan lebih pada makna atau pesan yang disampaikan, sehingga hal paling penting dalam terjemahan adalah hasil terjemahan memiliki maksud dan makna yang sama persis dengan pesan bahasa sumbernya.

Ahli bahasa bernama Jiri Levy dalam kumpulan esai "To Honor Roman Jakobson: Essays on the Occasion of His Seventieth Birthday II', memaparkan bahwa penerjemahan adalah dari sudut pandang teleologi: penerjemahan adalah sebuah proses komunikasi, yang memiliki tujuan untuk menyampaikan informasi dari bahasa sumber kepada para pembaca bahasa sasaran. Dari sudut pandang pragmatik:

\section{PELAKSANAAN KEGIATAN}

\section{Realisasi Pemecahan masalah}

\section{a. Persiapan Kegiatan pengabdian pada masyarakat}

Sebelum kegiatan dilaksanakan maka dilakukan persiapan-persiapan sebagai berikut:

1) Melakukan studi pustaka tentang berbagai media pembelajaran business writing, khususnya business correspondence.

2) Melakukan studi pustaka tentang berbagai media pembelajaran translation, khususnya modern translation tools.

3) Melakukan persiapan alat dan bahan untuk melatih peserta.

4) Menentukan waktu pelaksanaan dan lamanya kegiatan pengabdian bersama-sama tim pelaksana.

5) Menentukan dan mempersiapkan materi yang akan disampaikan dalam kegiatan pengabdian masyarakat.

\section{b. Pelaksanaan kegiatan pengabdian}

Pelaksanaan kegiatan pengabdian berlangsung pada hari Rabu, 30 Oktober 2019 dari jam 08.00 WIB s.d 12.00 WIB, dengan dihadiri 22 orang peserta, yaitu siswa SMK Ksatrya kelas XII, Rawasari, Jakarta Pusat. Kegiatan berupa penyampaian materi dan praktek langsung menggunakan translation tools secara online. Siswa secara bergiliran maju ke depan dan mencoba menggunakan metode terjemahan menggunakan aplikasi Grammarly. Setiap pesera diberikan kesempatan melakukan praktek langsung setelah penjelasan oleh tim instruktur.

\section{c. Khalayak Sasaran}

Khalayak sasaran yang dipilih adalah siswa SMK Ksatrya, kelas XII. Tempat yang adalah SMK Ksatrya yang beralamat di Jl. Percetakan Negara No.555C, RT.2/RW.7, Rawasari, Kec. Cemp. Putih, Kota Jakarta Pusat, Daerah Khusus Ibukota Jakarta 10570. 


\section{d. Relevansi bagi Siswa}

Kegiatan pengabdian ini memiliki relevansi dengan kebutuhan peningkatan ketrampilan komunikasi non-verbal untuk siswa. Berdasarkan hasil survey sebelum pelaksanaan, siswa-siswa SMK masih/kadang mengalami kesulitan dalam berkomunikasi non-verbal atau secara tertulis, khusus menggunakan bahasa Inggris dengan guru, teman, atau pihak lain. Sebagian besar siswa yang memiliki masalah spesifik karena keterbatasan pengetahuan dan ketrampilan komunikasi dalam bidang Business Correspondence dan juga Translation. Sehingga dengan adanya pelatihan ini diharapkan para siswa dapat memiliki bekal dan lebih percaya diri dalam berkomunikasi secara verbal maupun nonverbal dengan pihak lain.

\section{Hasil Kegiatan}

\section{a. Hasil Lokakarya dan pelatihan}

Berdasarkan wawancara, tanya jawab dan pengamatan langsung selama kegiatan berlangsung, kegiatan pengabdian pada masyarakat ini memberikan hasil sebagai berikut:

1) meningkatnya pengetahuan dan pemahaman serta ketrampilan siswa akan Korespondensi Bisnis dan juga Metode terjemahan modern menggunakan translation tools secara online.

2) Meningkatkan keberanian dan rasa percaya diri siswa untuk berani berkomunikasi secara verbal dan non-verbal sebelum, selama dan setelah pelatihan.

3) Mempererat tali silaturahim antara pihak Institut STIAMI, khusus para narasumber dengan pihak sekolah SMK Ksatrya.

\section{b. Faktor pendukung dan faktor penghambat}

Beberapa faktor yang mendukung terlaksananya kegiatan pengabdian pada masyarakat ini adalah besarnya minat dan antusiasme peserta selama kegiatan, sehingga kegiatan berlangsung dengan lancar dan efektif. Sedangkan faktor-faktor yang menjadi penghambat keberhasilan kegiatan secara maksimal antara lain:

1) Keterbatasan waktu pelatihan.

Waktu pelatihan dilakukan selama 4 (empat) jam dimana dirasakan tidak cukup untuk memberikan pemahaman konsep serta aplikasi mengenai korespondensi bisnis menggunakan bahasa Inggris secara maksimal.

2) Kurangnya kemampuan berbahasa Inggris pada tingkatan lanjutan bagi para siswa SMK Ksatrya.

Kemampuan berbahasa Inggris para peserta masih berada pada tingkatan dasar hingga pra-lanjutan. Dalam korespondensi bisnis berbahasa Inggris, konten redaksi surat menyurat, dokumen dan lain-lain menggunakan tingkatan linguistik yang sudah advanced atau mahir sehingga banyak kosa kata maupun tata bahasa yang tidak dimengerti para peserta pelatihan tersebut.

3) Masih kurangnya ketersediaan alat-alat pendukung yang menunjang kegiatan, seperti proyektor untuk presentasi, alat peraga, audio untuk penunjang kegiatan, dan lain-lain.

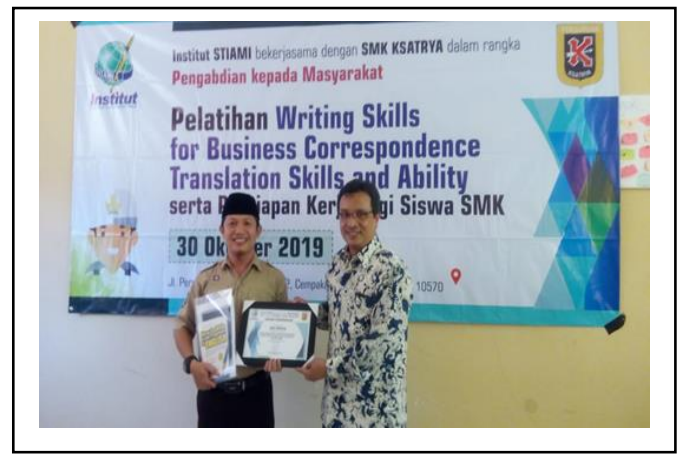

Gambar 1. Foto kegiatan PKM

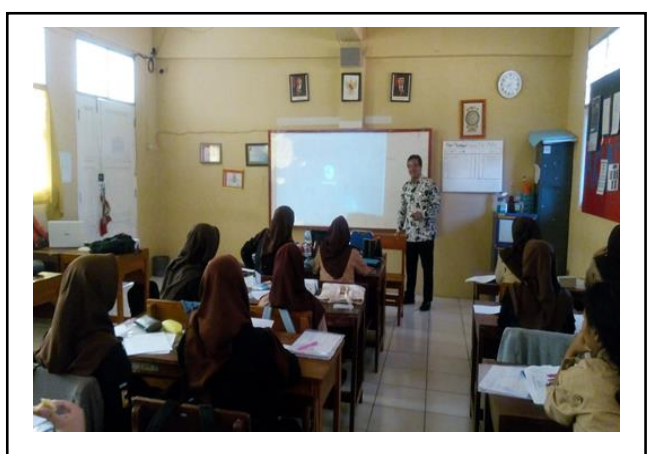

Gambar 2. Foto kegiatan PKM 


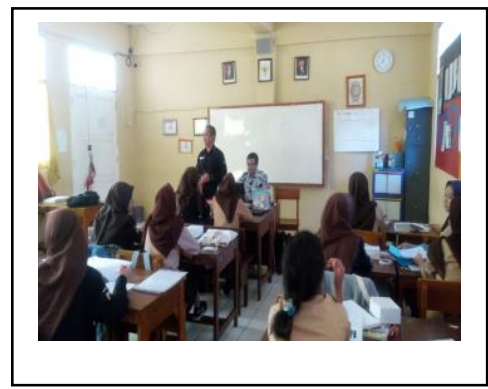

Gambar 3. Foto kegiatan PKM

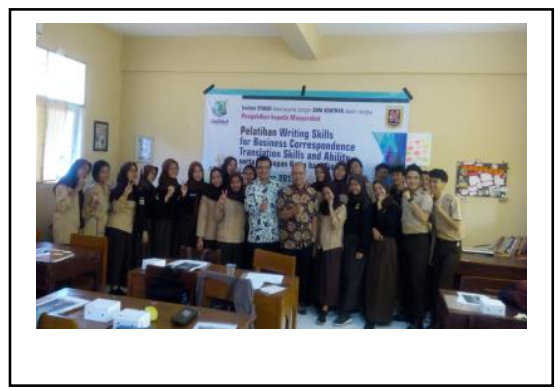

Gambar 4. Foto kegiatan PKM

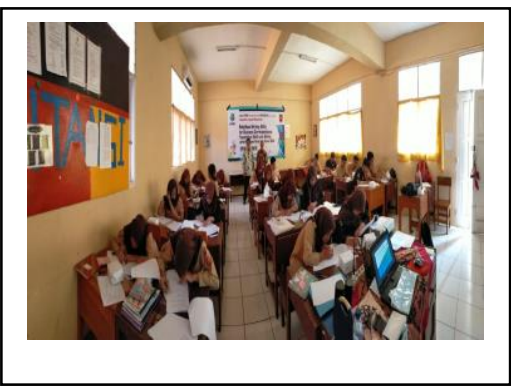

Gambar 5. Foto kegiatan PKM

\section{KESIMPULAN DAN SARAN}

\section{a. Kesimpulan}

Dari kegiatan pengabdian pada masyarakat ini dapat disimpulkan bahwa:

1. Pengetahuan dan pemahaman peserta pelatihan dalam melakukan komunikasi non-verbal khususnya business correspondence lebih meningkat. Indikator-indikator yang dapat menjelaskan peningkatan kemampuan berkomunikasi secara non-verbal antara lain:

2. Di awal pelatihan, penulis memberikan preliminary test atau tes awal yang dimaksudkan untuk mengetahui kemampuan serta keterampilan mereka terhadap korespondensi. Penulis memberikan lembar kerja yang berisi bagian-bagian dari sebut struktur surat bisnis dalam bahasa Inggris dan juga teks surat yang harus diterjemahkan ke bahasa Inggris. Para siswa diminta untuk mengerjakan tes tersebut dalam waktu 15 menit. Hasilnya adalah sebagian besar siswa tidak dapat menjawab dengan tepat soal-soal yang diberikan.

3. Di akhir pelatihan, penulis memberikan lagi lembar kerja sebagai evaluation test kepada para siswa. Materi tes adalah poin-poin penting dalam korespondensi bisnis dan naskah surat yang harus diterjemahkan ke dalam bahasa Inggris oleh para peserta. Hasilnya sebagian besar peserta dapat mengerjakan soal-soal dengan tepat.

4. Keterampilan dan pemahaman peserta pelatihan dalam melakukan proses penerjemahan, melakukan pemeriksaan hasil terjemahan dan memperbaiki hasil terjemahan secara online dan bersama-sama memberikan pemahaman yang lebih luas kepada para peserta pelatihan.

\section{b. Saran} perlu:

Mengingat besarnya manfaat kegiatan pengabdian pada masyarakat ini, maka selanjutnya

1. Mengadakan pelatihan serupa dan tidak terbatas hanya untuk siswa-siswa SMK saja tetapi juga untuk para siswa-siswa SMA.

2. Mengadakan pelatihan serupa untuk para guru-guru di SMK maupun di SMA Ksatrya.

3. Adanya kesinambungan dan monitoring program pasca kegiatan pengabdian ini sehingga siswa-siswa SMK benar-benar dapat mempraktekan ketrampilan yang sudah dimiliki.

\section{DAFTAR PUSTAKA}

Bram, B. (2012). Learners' Language Challenges in Writing English-A Journal of Culture. ELT \& Literature, CELT, 12(1), 1-100.

Djuharie, O. S. (2005). Panduan Membuat Karya Tulis. Bandung.

Locker, K., \& Stephen, K. (2015). Business Communication: Building Critical Skills. McGraw-Hill Higher Education.

M. Atar Semi, M. (2007). Dasar-dasar Ketrampilan Menulis. Bandung: Angkasa.

Machali, R. (2009). Pedoman Bagi Penerjemah. Bandung: Kaifa.

Nurgiantoro, B. (2009). Penilaian Dalam Pengajaran dan Sastra (3rd ed.). Yogyakarta: BPFE. 
Slamet, S. Y. (2008). Keterampilan Menulis Mahasiswa Ditinjau Dari Pengaruh Pendekatan Pembelajaran Dan Penguasaan Struktur Bahasa. Program Studi PGSD FKIP UNS.

Webster. (1993). Merriam-Webster's guide to business correspondence. Springfield: Mass.: MerriamWebster. 